\title{
Construction of the Pyrrolo[2,3- d]carbazole Core of Spiroindoline Alkaloids by Gold-Catalyzed Cascade Cyclization of Ynamide
}

\section{AUTHOR(S):}

Matsuoka, Junpei; Kumagai, Hiroshi; Inuki, Shinsuke; Oishi, Shinya; Ohno, Hiroaki

\section{CITATION:}

Matsuoka, Junpei ...[et al]. Construction of the Pyrrolo[2,3- d]carbazole Core of Spiroindoline Alkaloids by Gold-Catalyzed Cascade Cyclization of Ynamide. Journal of Organic Chemistry 2019, 84(14): 9358-9363

\section{ISSUE DATE:}

2019-07-19

URL:

http://hdl.handle.net/2433/243213

\section{RIGHT:}

This document is the Accepted Manuscript version of a Published Work that appeared in final form in Journal of Organic Chemistry, copyright @ A American Chemical Society after peer review and technical editing by the publisher. To access the final edited and published work see https://doi.org/10.1021/acs.joc.9b01149.; The full-text file will be made open to the public on 3 June 2020 in accordance with publisher's 'Terms and Conditions for Self-Archiving'.; This is not the published version. Please cite only the published version.; この論文は出版社版でありません。引用の際には出版社 版をご確認ご利用ください。 


\title{
Construction of the Pyrrolo[2,3-d]carbazole Core of Spiroindoline Alka- loids by Gold-Catalyzed Cascade Cyclization of Ynamide
}

\author{
Junpei Matsuoka, Hiroshi Kumagai, Shinsuke Inuki, Shinya Oishi, and Hiroaki Ohno* \\ Graduate School of Pharmaceutical Sciences, Kyoto University, Sakyo-ku, Kyoto 606-8501, Japan. \\ Supporting Information Placeholder
}

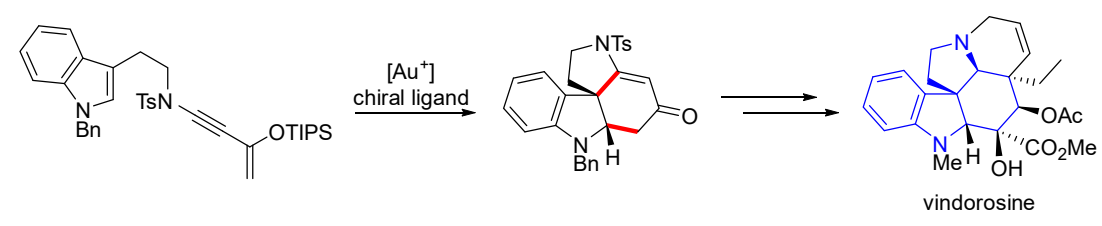

\begin{abstract}
We achieved direct construction of the common pyrrolo[2,3- $d]$ carbazole core of aspidosperma and malagasy alkaloids by a gold-catalyzed cascade cyclization of ynamide. This reaction involves intramolecular cyclization from indole to ynamide followed by trapping of the resulting iminium intermediate. Through the use of chiral gold complexes, an enantiomerically enriched pyrrolo[2,3- $d]$ carbazole was obtained in up to $74 \%$ ee. This methodology was successfully applied to the asymmetric formal synthesis of vindorosine.
\end{abstract}

Terpene indole alkaloids are a large family of nitrogencontaining metabolic compounds derived from various plants. Among them, aspidosperma-type alkaloids, including more than 250 members, constitute the largest family of terpene indole alkaloids. ${ }^{1}$ These alkaloids have important biological activities: for example, vinblastine and vincristine are used clinically as anticancer therapeutics. ${ }^{2}$ Vindorosine and vindoline (Figure 1), isolated from Cantharanthus Roseus, ${ }^{3}$ share features of the structure of vinblastine. Malagasy alkaloids, including malagashanol, were isolated from the stem bark of the Madagascan shrub Strychnos myrtoides in $1994 .{ }^{4}$ They were reported to have potentials for a chloroquine-enhancing action. The common structural feature of these alkaloids is the pyrrolo[2,3- $d]$ carbazole, where a highly substituted spirocyclic indoline is fused with a cyclohexane ring bearing continuous stereocenters (A-C \& E ring system of aspidosperma alkaloids (Figure 1).

The structural complexity and biological activities of vindorosine have inspired the synthetic community. Since the first total synthesis of vindorosine reported by the Büchi group in $1971,{ }^{5}$ various efficient total syntheses have been reported including Kuehne's first asymmetric total synthesis in $1987 .^{6}$ Recently, the groups of Boger ${ }^{7}$ and Zhang $^{8}$ reported their asymmetric total syntheses via tandem intermolecular DielsAlder/1,3-dipolar cycloaddition of 1,3,4-oxadiazoles or intramolecular Heathcock/aza-Prins cyclization, respectively. However, to the best of our knowledge, the asymmetric syntheses reported to date have relied on chiral pool strategies or diastereoselective reactions with the use of chiral auxiliaries. Thus, the total synthesis of vindorosine based on a catalytic asymmetric reaction remains challenging. We expected gold catalysis would provide an efficient approach to vindorosine and related alkaloids in an enantioselective manner.

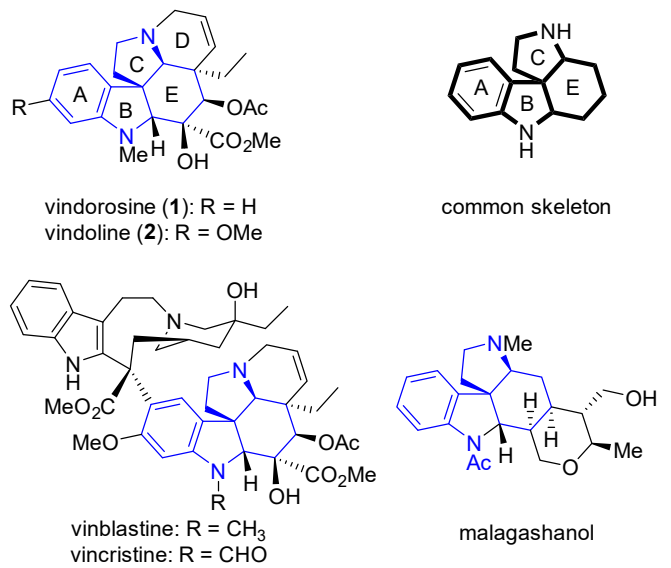

Figure 1. Polycyclic spiroindoline alkaloids.

Gold-catalyzed annulation of ynamides has emerged as a useful strategy for the construction of polycyclic nitrogen heterocycles. ${ }^{9-12}$ Following Dankwardt's report, a number of effective synthetic approaches to the construction of cyclic structures based on a gold-catalyzed cyclization of alkyne and silyl enol ether have been developed. ${ }^{13}$ We envision that a gold-catalyzed annulation of ynamides bearing a silyl enol ether moiety would provide direct access to pyrrolo[2,3$d]$ carbazole, the common tetracyclic indoline core of aspidosperma and malagasy alkaloids. Our working hypothesis is shown in Scheme 1a. Activation of the triple bond of ynamide A would promote nucleophilic attack at the indole 3 position to generate the spiroindoline intermediate $\mathbf{B}$. The subsequent addition of silyl enol ether to the resulting iminium moiety 
leads to the formation of intermediate $\mathbf{C}$, followed by deauration and cleavage of the silyl group to produce pyrrolo[2,3$d$ ] carbazole D. During the course of this study, a related goldcatalyzed cascade cyclization was reported by Yang and coworkers, ${ }^{12}$ where the iminium intermediate was trapped by intramolecular nucleophilic attack of hydroxy group (Scheme 1b). Quite recently, the Cheng and Liu group ${ }^{14}$ reported an acid-catalyzed cascade reaction of ynamide for the racemic synthesis of pyrrolo[2,3- $d$ ] carbazole D using methyl ketone derivative $\mathbf{G}$ (Scheme 1c). Herein, we describe a goldcatalyzed cascade reaction of ynamide with silyl enol ether, leading to pyrrolo[2,3- $d]$ carbazole $\mathbf{D}$. A catalytic enantioselective version of the reaction and its application to formal synthesis of vindorosine are also presented.

\section{Scheme 1. Intramolecular Cascade Reaction of Indole- Ynamides}

(a) This Work: gold-catalyzed cyclization with C-C bond formation

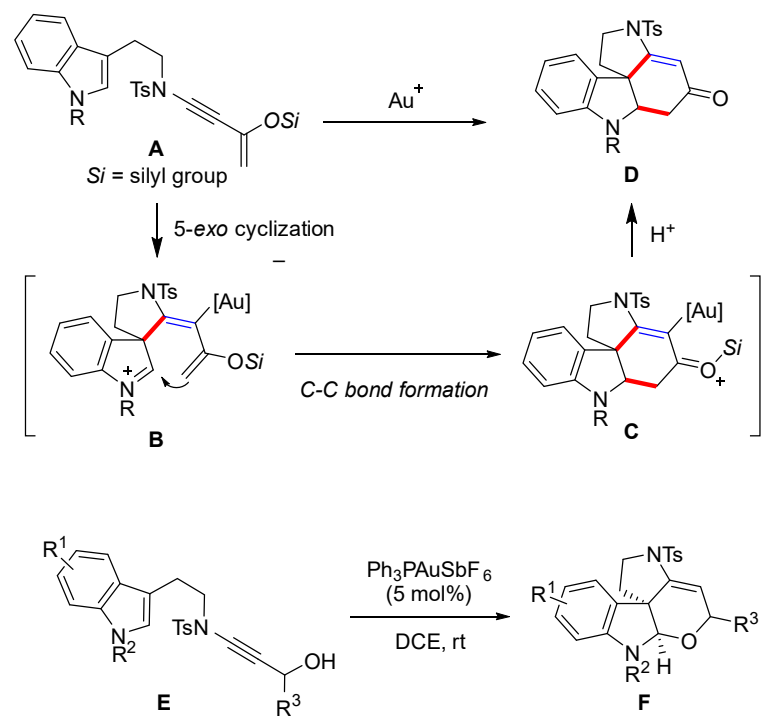

(c) acid-catalyzed cyclization with C-C bond formation (Cheng) ${ }^{14}$

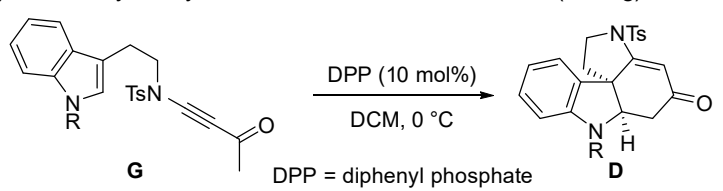

The preparation of silyl enol ether 7 is shown in Scheme 2. The protected tryptamine $\mathbf{3}$, prepared by tosylation and benzylation of tryptamine, was treated with trichloroethene (TCE) and $\mathrm{Cs}_{2} \mathrm{CO}_{3}$ to give dichloroenamine 4 in $99 \%$ yield. Dehydrochlorination-lithiation of $\mathbf{4}$ with $\mathrm{PhLi}$ and subsequent addition to acetaldehyde resulted in ynamide $\mathbf{5}$ bearing a secondary hydroxy group in $98 \%$ yield. ${ }^{15}$ Silyl enol ether 7 was then formed through a two-step sequence involving oxidation of $\mathbf{5}$ with $\mathrm{MnO}_{2}$ and subsequent silylation of ketone $\mathbf{6}$. Note that ketone $\mathbf{6}$ was not isolated because of its instability on silica gel. ${ }^{16}$

We then explored the optimal conditions for the goldcatalyzed cascade cyclization (Table 1). The treatment of methyl ketone 6 with JohnPhosAuSbF 6 led to recovery of the unreacted starting material without providing the desired product (entry 1). We next performed the reaction of silyl enol ether 7 with JohnPhosAuSbF 6 . Rewardingly, the expected cascade cyclization proceeded smoothly to afford the desired tetracyclic indoline 8 in $74 \%$ yield (entry 2 ). Considering that the demetalation of the vinylgold intermediate of type $\mathbf{C}$ requires protonation, ${ }^{13}$ we next evaluated the influence of additional proton sources. Among $i-\mathrm{PrOH}, \mathrm{AcOH}$, and TFA (entries 3-5), only $i-\mathrm{PrOH}$ had a positive effect on the yield of the desired product $8(79 \%$, entry 3$)$. Finally, optimization of the ligands (entries 6-8) revealed that IPr was most effective in terms of the yield of the desired product ( $91 \%$, entry 8$)$.

Scheme 2. Synthesis of Indole-Ynamide Having a Silyl Enol Ether
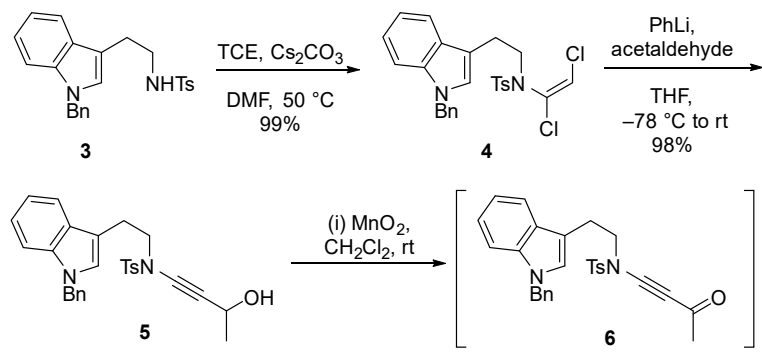<smiles>C=C(C#CNCCc1c[nH]c2ccccc12)O[SnH2]</smiles>

Table 1. Optimization of the Racemic Reaction ${ }^{a}$

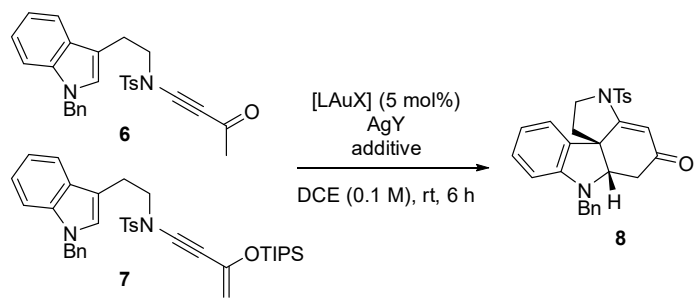

\begin{tabular}{|c|c|c|c|c|c|}
\hline entry & substrate & $\mathbf{L A u X} X^{b}$ & $\mathrm{AgY}$ & additive & $\begin{array}{l}\text { yield } \\
(\%)^{f}\end{array}$ \\
\hline $1^{c}$ & $6^{d}$ & $\mathbf{L 1 A u S b F}_{6}$ & - & - & ND \\
\hline 2 & $7^{e}$ & $\mathbf{L 1 A u S b F}_{6}$ & - & - & 74 \\
\hline 3 & $7^{e}$ & $\mathbf{L 1 A u S b F}_{6}$ & - & $i$-PrOH & 79 \\
\hline 4 & $7^{e}$ & $\mathbf{L 1} \mathrm{AuSbF}_{6}$ & - & $\mathrm{AcOH}$ & 61 \\
\hline 5 & $7^{e}$ & $\mathbf{L 1 A u S b F}_{6}$ & - & TFA & 68 \\
\hline 6 & $7^{e}$ & $\mathbf{L} \mathbf{1 A u C l}$ & $\mathrm{AgSbF}_{6}$ & $i$-PrOH & 63 \\
\hline 7 & $7^{e}$ & $\mathrm{Ph}_{3} \mathrm{PAuCl}$ & $\mathrm{AgSbF}_{6}$ & $i$-PrOH & 69 \\
\hline 8 & $7^{e}$ & IPrAuCl & $\mathrm{AgSbF}_{6}$ & $i$-PrOH & 91 \\
\hline
\end{tabular}

${ }^{a}$ Reaction condition: substrate (6 or 7, 1 equiv), $\mathrm{Au}(\mathrm{I}) \cdot$ ligand (5 mol \%), AgY (5 mol \%), 1,2-dichloroethane (DCE), additive (10 equiv where applicable) rt. ${ }^{b}$ Catalysts were prepared in situ by mixing AuCl-ligand with AgY, except for JohnPho$\mathrm{sAu}(\mathrm{MeCN}) \mathrm{SbF}_{6}$ (prepared in advance). The ligand structures are shown below. ${ }^{c}$ Reaction was performed for $24 \mathrm{~h} .{ }^{d}$ Crude substrate was used owing to the instability of $\mathbf{6}$ on silica gel. ${ }^{e}$ Includ- 
ing TIPSOH $(9-15 \%) .{ }^{f}$ Isolated yields based on the purity of 7 (85-91\%).

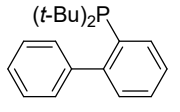

L1: JohnPhos

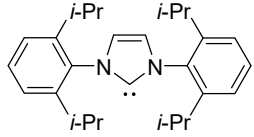

Next we proceeded to investigate the asymmetric goldcatalyzed cascade reaction. We focused on the biaryl-type chiral ligands, which are known to act as efficient ligands for gold-catalyzed asymmetric reactions in the previous reports (Table 2). ${ }^{12,17-19}$ We tested cationic binuclear gold complexes derived from chiral $C_{2}$-symmetrical bis-phosphine ligands L25 in the cascade reaction (entries 1-4) and found that DTBMBINAP ( $\mathbf{L 3}$, entry 2$)$ gave the most promising result $(58 \%$ yield, $50 \%$ ee). Evaluation of the counterions using $\mathbf{L 3}$ (entries 5-7) revealed that sodium tetrakis[3,5-bis(trifluoromethyl)phenyl]borate (NaBARF) improved the enantioselectivity to $72 \%$ but decreased the yield of (-)-8 to $38 \%$ (entry 7 ). A slight increase in enantioselectivity was observed when using a DTBM-SEGPHOS complex, L5 $\mathrm{Au}_{2} \mathrm{Cl}_{2} / \mathrm{NaBARF}$, (38\% yield, $74 \%$ ee, entry 8 ). Unfortunately, further investigations on the reaction temperature and catalyst loading did not further improve the yield (see Supporting Information).

Table 2. Optimization of the Asymmetric Reaction ${ }^{a}$
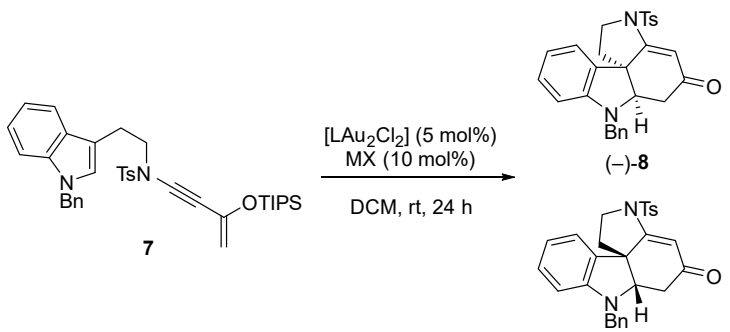

$(+)-8$

\begin{tabular}{|c|c|c|c|c|}
\hline entry & $\mathbf{L A u _ { 2 }} \mathrm{Cl}_{2}{ }^{b}$ & MX & yield $(\%)^{c}$ & $\% e e^{d}$ \\
\hline 1 & $\mathbf{L} 2 \mathrm{Au}_{2} \mathrm{Cl}_{2}$ & $\mathrm{AgBF}_{4}$ & trace & $2(-)$ \\
\hline 2 & $\mathbf{L} 3 \mathrm{Au}_{2} \mathrm{Cl}_{2}$ & $\mathrm{AgBF}_{4}$ & 58 & $50(-)$ \\
\hline 3 & $\mathbf{L} 4 \mathrm{Au}_{2} \mathrm{Cl}_{2}$ & $\mathrm{AgBF}_{4}$ & 23 & $12(-)$ \\
\hline 4 & $(R)-\mathbf{L} 5 \mathrm{Au}_{2} \mathrm{Cl}_{2}$ & $\mathrm{AgBF}_{4}$ & 30 & $52(-)$ \\
\hline 5 & $\mathbf{L} 3 \mathrm{Au}_{2} \mathrm{Cl}_{2}$ & $\mathrm{AgSbF}_{6}$ & 32 & $54(-)$ \\
\hline 6 & $\mathbf{L} 3 \mathrm{Au}_{2} \mathrm{Cl}_{2}$ & $\mathrm{LiB}\left(\mathrm{C}_{6} \mathrm{~F}_{5}\right)_{4}$ & 17 & $38(-)$ \\
\hline 7 & $\mathbf{L} 3 \mathrm{Au}_{2} \mathrm{Cl}_{2}$ & NaBARF & 38 & $72(-)$ \\
\hline 8 & $(R)-\mathbf{L} 5 \mathrm{Au}_{2} \mathrm{Cl}_{2}$ & NaBARF & 38 & $74(-)$ \\
\hline 9 & $(S)-\mathbf{L} \mathbf{5} \mathrm{Au}_{2} \mathrm{Cl}_{2}$ & NaBARF & 33 & $72(+)$ \\
\hline
\end{tabular}

${ }^{a}$ Reaction condition: 7 (including 9-15\% TIPSOH, 1 equiv), $\mathrm{Au}(\mathrm{I})$ ligand (5 mol \%), MX (10 mol \%), dichloromethane (DCM). ${ }^{b}$ Unless otherwise noted the catalysts were prepared in situ by mixing $\mathrm{AuCl} \cdot$ ligand with MX. Ligand structures are shown below. ${ }^{c}$ Isolated yields based on the purity of 7 (85-91\%). ${ }^{d}$ Determined by chiral HPLC analysis.

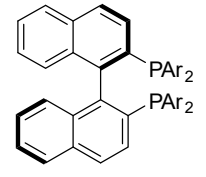

L2: $\mathrm{Ar}=\mathrm{Ph}$

L3: $\mathrm{Ar}=\mathrm{C}_{6} \mathrm{H}_{2}\left[3,5-(t-\mathrm{Bu})_{2}\right](4-\mathrm{OMe})$ L4: $\mathrm{Ar}=\mathrm{C}_{6} \mathrm{H}_{2}\left(3,5-\mathrm{Me}_{2}\right)\left(4-\mathrm{NMe}_{2}\right)$

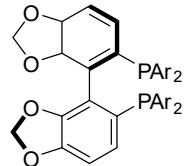

$(R)$-L5

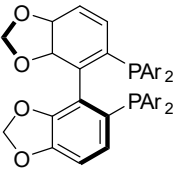

$(S)$-L5
$\mathrm{Ar}=\mathrm{C}_{6} \mathrm{H}_{2}\left[3,5-(t-\mathrm{Bu})_{2}\right](4-\mathrm{OMe})$

To reveal the absolute configuration of optically active $\mathbf{8}$ prepared by the reaction of 7 and a chiral gold catalyst, we synthesized hydrazone $\mathbf{1 0}$ bearing a chiral hydrazine $\mathbf{9}$ from racemic 8 (Scheme 3). After separation of diastereomers by column chromatography, the absolute configuration of $\mathbf{1 0}$ was confirmed by X-ray analysis (Figure 2 ). Then we obtained the authentic sample of $(S, S)-(+)-\mathbf{8}$ by the reaction of $\mathbf{1 0}$ with MeI and $\mathrm{H}_{2} \mathrm{O}$. This experiment has revealed that $(-)-8$ has the opposite configuration to that of natural vindorosine. Thus, we prepared $(+)-\mathbf{8}$ by the reaction using $(S)-\mathbf{L 5} \mathrm{AuCl}_{2}$ (Table 2 , entry 9).

Scheme 3. Determination of Absolute Configuration of 8
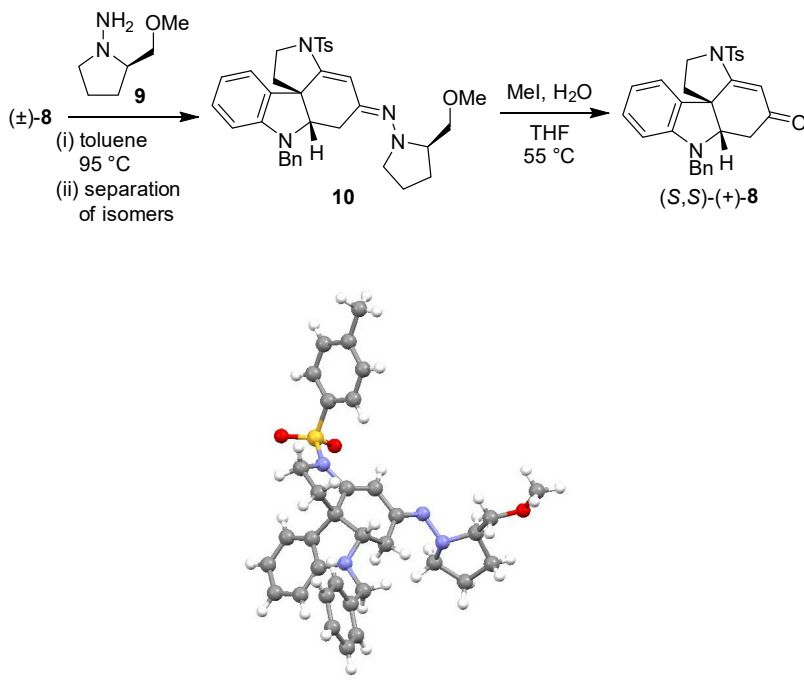

Figure 2. X-ray structure of $\mathbf{1 0}$. There are two crystallographically independent molecules in the single crystal lattices, one of which is shown for clarity.

We finally applied the catalytic asymmetric synthesis of pyrrolo[2,3- $d]$ carbazole 8 to formal total synthesis of vindorosine (Scheme 4). The annulation of 7 was carried out on a 1.3 mmol scale to produce $(+)-8$ in $68 \%$ ee $(21 \%$ isolated yield in three steps from 5). The subsequent removal of the benzyl group and $N$-methylation afforded the known precursor 11 in $65 \%$ yield, which can be converted to vindorosine (1) as reported by Cheng. ${ }^{14}$ 
Scheme 4. Formal Synthesis of Vindorosine
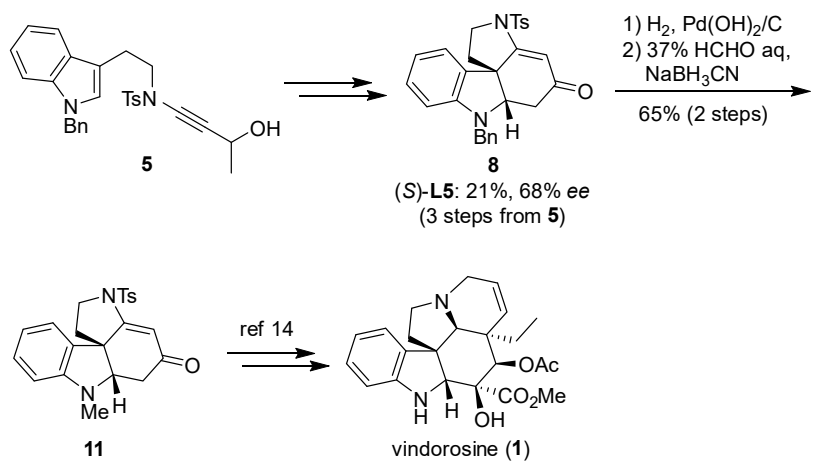

In conclusion, we have developed a new method for the construction of the pyrrolo[2,3- $d]$ carbazole core of aspidosperma alkaloids based on a gold-catalyzed cascade reaction of ynamide with silyl enol ether. Notably, enantioselective synthesis of the pyrrolo[2,3-d]carbazole was also achieved in up to $74 \%$ ee. The developed reaction provides ready access to the synthetic intermediate of vindorosine.

\section{Experimental Section}

\section{General Methods}

IR spectra were determined on a JASCO FT/IR-4100 spectrometer. Exact mass (HRMS) spectra were recorded on JMS-HX mass spectrometer or Shimadzu LC-ESI-IT-TOF-MS equipment. ${ }^{1} \mathrm{H}$ NMR spectra were recorded using a JEOL ECA-400 or JEOL ECA-500 spectrometer at a $500 \mathrm{MHz}$ frequency. Chemical shifts are reported in $\delta(\mathrm{ppm})$ relative to $\mathrm{Me}_{4} \mathrm{Si}$ (in $\mathrm{CDCl}_{3}$ ) as an internal standard. ${ }^{13} \mathrm{C}$ NMR spectra were recorded using a JEOL ECA-500 unit and referenced to the residual solvent signal. Melting points were measured by a hot stage melting point apparatus (uncorrected). For column chromatography, silica gel (Wakogel C-200E: Wako Pure Chemical Industries, Ltd) or amine silica gel (CHROMATOREX NH-DM1020: Fuji Silysia Chemical Ltd.) was employed. Chiral chromatography was performed with a Cosmosil CHiRAL 5B column $(4.6 \mathrm{~mm} \times 250$ $\mathrm{mm}$, Nacalai Tesque Inc.) or CHIRALCEL OD-H column $(4.6 \mathrm{~mm} \times$ $250 \mathrm{~mm}$, Daicel Inc.) with using $n$-hexane $/ i-\mathrm{PrOH}$ as an eluent. The gold complexes (R)-DTBM-SEGPHOS $(\mathrm{AuCl})_{2}, \quad(S)$-DTBM-

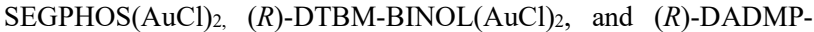
$\operatorname{BINOL}(\mathrm{AuCl})_{2}$ were prepared according to the literature. ${ }^{18,19}$

\section{Preparation of the Cyclization Precursor}

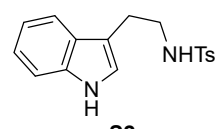

S2

$\boldsymbol{N}$-[2-(1H-Indol-3-yl)ethyl]-4-methylbenzenesulfonamide (S2). To a solution of tryptamine $(\mathbf{S 1})(9.61 \mathrm{~g}, 60.0 \mathrm{mmol})$ and $\mathrm{Et}_{3} \mathrm{~N}(9.20 \mathrm{~mL}$, $66.0 \mathrm{mmol})$ in $\mathrm{CH}_{2} \mathrm{Cl}_{2}(90 \mathrm{~mL})$ at $0{ }^{\circ} \mathrm{C}$ was added $p$ - $\mathrm{TsCl}(13.7 \mathrm{~g}$, $72.0 \mathrm{mmol}$ ) in one portion. After the mixture was stirred for $2 \mathrm{~h}$ at room temperature, the reaction was quenched with $1 \mathrm{M} \mathrm{HCl}$ and neutralized with $1 \mathrm{M} \mathrm{NaOH}$. The resulting mixture was extracted with $\mathrm{CH}_{2} \mathrm{Cl}_{2}$ twice. The organic layer was washed with brine, dried over $\mathrm{MgSO}_{4}$, filtered, and concentrated in vacuo. The residue was filtered through a short pad of $\mathrm{NH}_{2}$ silica gel with $\mathrm{CHCl}_{3}$ to afford $\mathbf{S 2}(18.9 \mathrm{~g}$, $60.0 \mathrm{mmol}, 100 \%$ ) as a white solid. This material was recrystallized from $\mathrm{CHCl}_{3}$ to afford pure $\mathbf{S 2}$ as colorless needles: $\mathrm{mp} 112-114{ }^{\circ} \mathrm{C}$; IR $\left(\mathrm{CDCl}_{3}\right) 3406(\mathrm{~N}-\mathrm{H}), 1319(\mathrm{O}=\mathrm{S}=\mathrm{O}), 1152(\mathrm{O}=\mathrm{S}=\mathrm{O}) ;{ }^{1} \mathrm{H}$ NMR $\left(500 \mathrm{MHz}, \mathrm{CDCl}_{3}\right) \delta 2.37(\mathrm{~s}, 3 \mathrm{H}), 2.90(\mathrm{t}, J=6.6 \mathrm{~Hz}, 2 \mathrm{H}), 3.24(\mathrm{td}, J$ $=6.6,6.0 \mathrm{~Hz}, 2 \mathrm{H}), 4.58(\mathrm{t}, J=6.0 \mathrm{~Hz}, 1 \mathrm{H}), 6.92(\mathrm{~d}, J=2.3 \mathrm{~Hz}, 1 \mathrm{H})$, $7.04(\mathrm{dd}, J=7.4,7.4 \mathrm{~Hz}, 1 \mathrm{H}), 7.15-7.19(\mathrm{~m}, 3 \mathrm{H}), 7.32(\mathrm{~d}, J=8.6 \mathrm{~Hz}$ $1 \mathrm{H}), 7.39$ (d, $J=7.4 \mathrm{~Hz}, 1 \mathrm{H}), 7.62(\mathrm{~d}, J=8.0 \mathrm{~Hz}, 2 \mathrm{H}), 8.12(\mathrm{br} \mathrm{s}$, $1 \mathrm{H}) ;{ }^{13} \mathrm{C}\left\{{ }^{1} \mathrm{H}\right\}$ NMR $\left(125 \mathrm{MHz}, \mathrm{CDCl}_{3}\right) \delta 21.4,25.4,43.0,111.3$, $111.4,118.4,119.4,122.1,122.6,126.8,127.0$ (2C), $129.6(2 \mathrm{C})$ 136.3, 136.6, 143.3; HRMS (ESI) calcd for $\mathrm{C}_{17} \mathrm{H}_{18} \mathrm{~N}_{2} \mathrm{NaO}_{2} \mathrm{~S}^{+}[\mathrm{M}+$ $\mathrm{Na}]^{+}$337.0981, found 337.0982 .

$\mathrm{N}$-[2-(1-Benzyl-1 $\mathrm{H}$-indol-3-yl)ethyl]-4-methylbenzenesulfonamide (3). To a solution of S2 $(18.9 \mathrm{~g}, 60.0 \mathrm{mmol})$ in dry DMF $(200 \mathrm{~mL})$ was slowly added $\mathrm{NaH}(60 \%$ dispersion in mineral oil, $8.40 \mathrm{~g}, 210$ $\mathrm{mmol}$ ) at room temperature under argon, and stirring continued at this temperature for $30 \mathrm{~min}$. The solution was cooled to $0{ }^{\circ} \mathrm{C}$, and $\mathrm{BnBr}$ $(7.09 \mathrm{~mL}, 60.0 \mathrm{mmol})$ was added dropwise. After being stirred for $2 \mathrm{~h}$, the reaction mixture was allowed to warm up to room temperature and stirred overnight. The reaction mixture was diluted with sat. $\mathrm{NH}_{4} \mathrm{Cl}$ and extracted with EtOAc. The combined organic layer was washed with water and brine and dried over $\mathrm{MgSO}_{4}$. After concentration in vacuo, the residue was purified by flash chromatography on silica gel (hexane/EtOAc $=4 / 1 \rightarrow 3 / 1)$ to afford $3(19.2 \mathrm{~g}, 47.5 \mathrm{mmol}, 79 \%)$ as a pale yellow solid: $\mathrm{mp} 90-93{ }^{\circ} \mathrm{C}$; IR $\left(\mathrm{CDCl}_{3}\right) 3278(\mathrm{~N}-\mathrm{H}), 1323$ $(\mathrm{O}=\mathrm{S}=\mathrm{O}), 1154(\mathrm{O}=\mathrm{S}=\mathrm{O}) ;{ }^{1} \mathrm{H}$ NMR $\left(500 \mathrm{MHz}, \mathrm{CDCl}_{3}\right) \delta 2.38(\mathrm{~s}, 3 \mathrm{H})$, $2.91(\mathrm{t}, J=6.9 \mathrm{~Hz}, 2 \mathrm{H}), 3.26(\mathrm{td}, J=6.9,5.7 \mathrm{~Hz}, 2 \mathrm{H}), 4.48(\mathrm{~d}, J=5.7$ $\mathrm{Hz}, 1 \mathrm{H}), 5.23(\mathrm{~s}, 2 \mathrm{H}), 6.85(\mathrm{~s}, 1 \mathrm{H}), 7.04(\mathrm{dd}, J=7.7,7.7 \mathrm{~Hz}, 1 \mathrm{H})$, 7.09 (d, $J=6.9 \mathrm{~Hz}, 2 \mathrm{H}), 7.14-7.19(\mathrm{~m}, 3 \mathrm{H}), 7.24-7.31(\mathrm{~m}, 4 \mathrm{H}), 7.41$ $(\mathrm{d}, J=8.0 \mathrm{~Hz}, 1 \mathrm{H}), 7.62(\mathrm{~d}, J=8.0 \mathrm{~Hz}, 2 \mathrm{H}) ;{ }^{13} \mathrm{C}\left\{{ }^{1} \mathrm{H}\right\}$ NMR $(125$ $\left.\mathrm{MHz}, \mathrm{CDCl}_{3}\right) \delta 21.5,25.4,43.1,49.9,109.8,110.7,118.7,119.2$, $122.0,126.5,126.8(2 \mathrm{C}), 127.0(2 \mathrm{C}), 127.5,127.7,128.8(2 \mathrm{C}), 129.6$ (2C), 136.76, 136.78, 137.3, 143.2. Anal. calcd for $\mathrm{C}_{24} \mathrm{H}_{24} \mathrm{~N}_{2} \mathrm{O}_{2} \mathrm{~S}$ : C, 71.26; H, 5.98; N, 6.93. Found: C, 71.18; H, 6.00; N, 6.89.

(E)- $N$-[2-(1-Benzyl-1H-indol-3-yl)ethyl]- $N$-(1,2-dichlorovinyl)-4methylbenzenesulfonamide (4). To a solution of 3 (19.2 g, 47.4 $\mathrm{mmol})$ and $\mathrm{Cs}_{2} \mathrm{CO}_{3}(23.2 \mathrm{~g} 52.1 \mathrm{mmol})$ in dry DMF $(47 \mathrm{~mL})$ was added dropwise trichloroethylene $(4.69 \mathrm{~mL}, 52.1 \mathrm{mmol})$ over $10 \mathrm{~min}$ at room temperature under argon. The reaction mixture was allowed to warm up to $50{ }^{\circ} \mathrm{C}$ and stirred for $1.5 \mathrm{~h}$. Upon cooling to room temperature, the reaction mixture was diluted with EtOAc, washed with water and brine, dried over $\mathrm{MgSO}_{4}$, filtered, and concentrated in vac$u o$. The residue was filtered through a short pad of silica gel (EtOAc) to afford 4 (23.4 g, $46.9 \mathrm{mmol}, 99 \%)$ as a pale yellow solid. This material was recrystallized from EtOAc to afford pure $\mathbf{4}$ as colorless needles: mp 103-107 ${ }^{\circ} \mathrm{C}$; IR $\left(\mathrm{CDCl}_{3}\right) 1357(\mathrm{O}=\mathrm{S}=\mathrm{O}), 1164(\mathrm{O}=\mathrm{S}=\mathrm{O})$; ${ }^{1} \mathrm{H}$ NMR $\left(500 \mathrm{MHz}, \mathrm{CDCl}_{3}\right) \delta 2.37(\mathrm{~s}, 3 \mathrm{H}), 3.03(\mathrm{t}, J=7.7 \mathrm{~Hz}, 2 \mathrm{H})$, $3.53(\mathrm{br} \mathrm{s}, 2 \mathrm{H}), 5.20(\mathrm{~s}, 2 \mathrm{H}), 6.51(\mathrm{~s}, 1 \mathrm{H}), 6.93(\mathrm{~s}, 1 \mathrm{H}), 7.07-7.09(\mathrm{~m}$, $3 \mathrm{H}), 7.15(\mathrm{dd}, J=7.7,7.7 \mathrm{~Hz}, 3 \mathrm{H}), 7.18-7.28(\mathrm{~m}, 4 \mathrm{H}), 7.51(\mathrm{~d}, J=$ $8.0 \mathrm{~Hz}, 1 \mathrm{H}), 7.75(\mathrm{~d}, J=8.0 \mathrm{~Hz}, 2 \mathrm{H}) ;{ }^{13} \mathrm{C}\left\{{ }^{1} \mathrm{H}\right\}$ NMR $(125 \mathrm{MHz}$, $\left.\mathrm{CDCl}_{3}\right) \delta 21.5,24.0,48.3,49.8,109.7,110.6,118.6,119.2,121.4$, $121.8,126.3,126.8(2 \mathrm{C}), 127.5,127.7,128.2(2 \mathrm{C}), 128.7$ (2C), 129.6 (3C), 135.0, 136.5, 137.3, 144.4. Anal. calcd for $\mathrm{C}_{26} \mathrm{H}_{24} \mathrm{Cl}_{2} \mathrm{~N}_{2} \mathrm{O}_{2} \mathrm{~S}$ : C, $62.53 ; \mathrm{H}, 4.84 ; \mathrm{N}, 5.61$. Found: C, 62.32; H, 4.77; N, 5.66.

$\mathrm{N}$-[2-(1-Benzyl-1H-indol-3-yl)ethyl]- $\mathrm{N}$-(3-hydroxybut-1-yn-1-yl)4-methylbenzenesulfonamide (5). To a solution of $4(2.50 \mathrm{~g}, 5.01$ $\mathrm{mmol})$ in dry THF $(50 \mathrm{~mL})$ was added $\mathrm{PhLi}(\mathrm{ca} .1 .6 \mathrm{M}$ in dibutyl ether, $6.88 \mathrm{~mL}, 11.0 \mathrm{mmol}$ ) dropwise at $-78{ }^{\circ} \mathrm{C}$ under argon, and stirring was continued at this temperature for $2 \mathrm{~h}$. After complete conversion to the intermediate (confirmed by TLC), acetaldehyde $(0.34 \mathrm{~mL}, 6.0 \mathrm{mmol})$ was added at $-78{ }^{\circ} \mathrm{C}$ and the reaction mixture was allowed to warm up to room temperature. After being stirred for $1 \mathrm{~h}$, the reaction mixture was diluted with water and extracted with EtOAc. The combined organic layers were washed with water and brine and dried over $\mathrm{MgSO}_{4}$. After concentration in vacuo, the residue was purified by flash chromatography on silica gel (hexane/EtOAc = 2/1) to afford $5(2.31 \mathrm{~g}, 4.89 \mathrm{mmol}, 98 \%)$ as an orange amorphous: IR $\left(\mathrm{CDCl}_{3}\right) 3407(\mathrm{O}-\mathrm{H}), 2240(\mathrm{C} \equiv \mathrm{C}), 1357(\mathrm{O}=\mathrm{S}=\mathrm{O}), 1165(\mathrm{O}=\mathrm{S}=\mathrm{O})$; ${ }^{1} \mathrm{H}$ NMR $\left(500 \mathrm{MHz}, \mathrm{CDCl}_{3}\right) \delta 1.41(\mathrm{~d}, J=6.9 \mathrm{~Hz}, 3 \mathrm{H}), 2.00(\mathrm{~d}, J=$ $5.2 \mathrm{~Hz}, 1 \mathrm{H}), 2.40(\mathrm{~s}, 3 \mathrm{H}), 3.08(\mathrm{t}, J=7.7 \mathrm{~Hz}, 2 \mathrm{H}), 3.57-3.66(\mathrm{~m}, 2 \mathrm{H})$, 4.57-4.62 (m, 1H), $5.21(\mathrm{~s}, 2 \mathrm{H}), 6.89(\mathrm{~s}, 1 \mathrm{H}), 7.09(\mathrm{~m}, 3 \mathrm{H}), 7.16(\mathrm{t}, J$ $=7.7 \mathrm{~Hz}, 1 \mathrm{H}), 7.23-7.29(\mathrm{~m}, 6 \mathrm{H}), 7.54(\mathrm{~d}, J=7.4 \mathrm{~Hz}, 1 \mathrm{H}), 7.71(\mathrm{~d}, J$ $=8.0 \mathrm{~Hz}, 2 \mathrm{H}) ;{ }^{13} \mathrm{C}\left\{{ }^{1} \mathrm{H}\right\}$ NMR $\left(125 \mathrm{MHz}, \mathrm{CDCl}_{3}\right) \delta 21.6,24.2,24.3$, 
$49.8,51.7,58.4,73.0,77.5,109.7,110.6,118.7,119.2,121.8,126.6$, 126.8 (2C), 127.5 (2C), 127.6, 127.8, 128.7 (2C), 129.6 (2C), 134.6, 136.5, 137.7, 144.5; HRMS (ESI) calcd for $\mathrm{C}_{28} \mathrm{H}_{29} \mathrm{~N}_{2} \mathrm{O}_{3} \mathrm{~S}^{+}[\mathrm{M}+\mathrm{H}]^{+}$ 473.1893, found 473.1887 .

\section{$N$-[2-(1-Benzyl-1 $H$-indol-3-yl)ethyl]-4-methyl- $N$ - $\{3-$}

[(triisopropylsilyl)oxy]but-3-en-1-yn-1-yl benzenesulfonamide (7). To a solution of $\mathbf{5}(5.57 \mathrm{~g}, 11.8 \mathrm{mmol})$ in dry $\mathrm{CH}_{2} \mathrm{Cl}_{2}(118 \mathrm{~mL})$ was added $\mathrm{MgO}(30.5 \mathrm{~g}, 353 \mathrm{mmol})$ at room temperature. After being stirred for $6 \mathrm{~h}$, the reaction mixture was filtered through Celite. The filtrate was concentrated in vacuo to afford the corresponding ketone 6. This material was used for the next reaction without further purification because of its instability toward silica gel. To a solution of the crude 6 and $\mathrm{Et}_{3} \mathrm{~N}(4.11 \mathrm{~mL}, 29.5 \mathrm{mmol})$ in dry $\mathrm{CH}_{2} \mathrm{Cl}_{2}(118 \mathrm{~mL})$ was added TIPSOTf $(3.96 \mathrm{~mL}, 14.7 \mathrm{mmol})$ dropwise at $-78{ }^{\circ} \mathrm{C}$ under argon, and the reaction mixture was allowed to warm up to room temperature. After being stirred for $2 \mathrm{~h}$, the reaction mixture was diluted with sat. $\mathrm{NH}_{4} \mathrm{Cl}$ and extracted with $\mathrm{CH}_{2} \mathrm{Cl}_{2}$. The combined organic extracts were washed with water and brine, dried over $\mathrm{Na}_{2} \mathrm{SO}_{4}$. After concentration in vacuo, the residue was purified by flash chromatography on $\mathrm{NH}_{2}$ silica gel (hexane/EtOAc $=12 / 1$ ) to afford $7(7.21 \mathrm{~g}, 11.5 \mathrm{mmol}, \mathrm{ca} .98 \%$; including a small amount of TIPSOH) as a pale yellow oil; IR $\left(\mathrm{CDCl}_{3}\right) 2229(\mathrm{C} \equiv \mathrm{C}), 1369$ $(\mathrm{O}=\mathrm{S}=\mathrm{O}), 1167(\mathrm{O}=\mathrm{S}=\mathrm{O}) ;{ }^{1} \mathrm{H}$ NMR $\left(500 \mathrm{MHz}, \mathrm{CDCl}_{3}\right) \delta 1.09(\mathrm{~d}, J=$ $7.5 \mathrm{~Hz}, 18 \mathrm{H}), 1.18-1.26(\mathrm{~m}, 3 \mathrm{H}), 2.41(\mathrm{~s}, 3 \mathrm{H}), 3.10(\mathrm{t}, J=8.1 \mathrm{~Hz}, 2 \mathrm{H})$ $3.64(\mathrm{t}, J=7.8 \mathrm{~Hz}, 2 \mathrm{H}), 4.63(\mathrm{~s}, 1 \mathrm{H}), 4.72(\mathrm{~s}, 1 \mathrm{H}), 5.24(\mathrm{~s}, 2 \mathrm{H}), 6.92$ (s, 1H), 7.08-7.12 (m, 3H), $7.17(\mathrm{t}, J=7.0 \mathrm{~Hz}, 1 \mathrm{H}), 7.23-7.31(\mathrm{~m}, 6 \mathrm{H})$ $7.55(\mathrm{~d}, J=7.5 \mathrm{~Hz}, 1 \mathrm{H}), 7.71(\mathrm{~d}, J=8.1 \mathrm{~Hz}, 2 \mathrm{H}) ;{ }^{13} \mathrm{C}\left\{{ }^{1} \mathrm{H}\right\} \mathrm{NMR}(125$ $\left.\mathrm{MHz}, \mathrm{CDCl}_{3}\right) \delta 12.5$ (3C), 17.9 (6C), 21.6, 24.3, 49.9, 52.0, 69.1, 79.8, $102.6,109.7,110.6,118.7,119.2,121.9,126.4,126.8(2 \mathrm{C}), 127.5$ (2C), 127.6, 127.8, 128.7 (2C), 129.7 (2C), 134.7, 136.5, 137.4, 139.6, 144.5; HRMS (ESI) calcd for $\mathrm{C}_{37} \mathrm{H}_{47} \mathrm{~N}_{2} \mathrm{O}_{3} \mathrm{SSS}^{+}[\mathrm{M}+\mathrm{H}]^{+}$627.3071, found 627.3071 .

\section{Gold-Catalyzed Cascade Cyclization}

$\left(6 \mathrm{a} R^{*}, 11 \mathrm{~b} R^{*}\right)$-7-Benzyl-3-tosyl-2,3,6a,7-tetrahydro- $1 H$ pyrrolo[2,3- $d]$ carbazol-5(6H)-one (8) (Table 1, Entry 8). To a solution of $7(62.7 \mathrm{mg}, 0.1 \mathrm{mmol})$ in DCE $(1 \mathrm{~mL})$ was added $\mathrm{IPrAuCl}(3.1$ $\mathrm{mg}, 5 \mathrm{~mol} \%), \mathrm{AgSbF}_{6}(1.7 \mathrm{mg}, 5 \mathrm{~mol} \%)$, and $i-\mathrm{PrOH}(77 \mu \mathrm{L}, 1.0$ mmol) at room temperature. After the mixture was stirred for $6 \mathrm{~h}$, TBAF ( $c a .1 \mathrm{M}$ in THF, $150 \mu \mathrm{L}, 0.15 \mathrm{mmol}$ ) was added. After being stirred for $30 \mathrm{~min}$ at room temperature, the reaction mixture was concentrated in vacuo. The residue was purified by flash chromatography on silica gel (hexane/EtOAc $=3 / 1)$ to afford $(+)-8(43.0 \mathrm{mg}, 0.091$ mmol, $91 \%$ ) as a yellow solid: $\mathrm{mp} 180-182{ }^{\circ} \mathrm{C}$; IR $\left(\mathrm{CDCl}_{3}\right) 1620$ $(\mathrm{C}=\mathrm{O}), 1360(\mathrm{O}=\mathrm{S}=\mathrm{O}), 1168(\mathrm{O}=\mathrm{S}=\mathrm{O}) ;{ }^{1} \mathrm{H}$ NMR $\left(500 \mathrm{MHz}, \mathrm{CDCl}_{3}\right)$ $\delta 1.98(\mathrm{ddd}, J=11.7,11.7,8.2 \mathrm{~Hz}, 1 \mathrm{H}), 2.10-2.15(\mathrm{~m}, 2 \mathrm{H}), 2.49$ (s, $3 \mathrm{H}), 2.51$ (dd, $J=16.6,6.3 \mathrm{~Hz}, 1 \mathrm{H}), 3.76(\mathrm{dd}, J=10.3,5.7 \mathrm{~Hz}, 1 \mathrm{H})$, $3.80(\mathrm{td}, J=10.9,5.3 \mathrm{~Hz}, 1 \mathrm{H}), 3.96(\mathrm{~d}, J=14.9 \mathrm{~Hz}, 1 \mathrm{H}), 4.04(\mathrm{dd}, J$ $=10.0,8.3 \mathrm{~Hz}, 1 \mathrm{H}), 4.43(\mathrm{~d}, J=14.9 \mathrm{~Hz}, 1 \mathrm{H}), 6.02(\mathrm{~d}, J=6.9 \mathrm{~Hz}$, $1 \mathrm{H}), 6.29(\mathrm{~s}, 1 \mathrm{H}), 6.46(\mathrm{~m}, 2 \mathrm{H}), 7.06-7.10(\mathrm{~m}, 1 \mathrm{H}), 7.27-7.30(\mathrm{~m}, 1 \mathrm{H})$, $7.32-7.37(\mathrm{~m}, 4 \mathrm{H}), 7.41(\mathrm{~d}, J=8.0 \mathrm{~Hz}, 2 \mathrm{H}), 7.88(\mathrm{~d}, J=8.6 \mathrm{~Hz}, 2 \mathrm{H})$; ${ }^{13} \mathrm{C}\left\{{ }^{1} \mathrm{H}\right\}$ NMR $\left(125 \mathrm{MHz}, \mathrm{CDCl}_{3}\right) \delta 21.6,35.2,35.4,48.7,48.9,53.8$, $67.4,106.5,109.1,118.7,122.0,127.2(2 \mathrm{C}), 127.6,127.8(2 \mathrm{C}), 128.7$ (2C), 129.1, 130.3 (2C), 130.5, 134.6, 136.9, 145.5, 148.1, 159.4, 196.4; HRMS (ESI) calcd for $\mathrm{C}_{28} \mathrm{H}_{27} \mathrm{~N}_{2} \mathrm{O}_{3} \mathrm{~S}^{+}[\mathrm{M}+\mathrm{H}]^{+} 471.1737$, found 471.1738

\section{Asymmetric Reaction Using DTBM-SEGPHOS(AuCl)2 (Table 2, Entry 9)}

To a solution of $7(62.7 \mathrm{mg}, 0.1 \mathrm{mmol})$ in DCM $(1.0 \mathrm{~mL})$ was added $(S)$-DTBM-SEGPHOS(AuCl $)_{2}(8.2 \mathrm{mg}, 5 \mathrm{~mol} \%)$ and NaBARF $(8.9$ $\mathrm{mg}, 10 \mathrm{~mol} \%$ ) at room temperature. After being stirred for $24 \mathrm{~h}$, the reaction mixture was concentrated in vacuo. The residue was purified by flash chromatography on silica gel (hexane/EtOAc $=3 / 1$ ) to afford $8(18.0 \mathrm{mg}, 0.038 \mathrm{mmol} 33 \%, 72 \% e e)$ as a yellow amorphous solid [HPLC, Chiralcel-OD-H column eluting with $65 \% i-\mathrm{PrOH} / n$-hexane over $30 \mathrm{~min}$ at $0.80 \mathrm{~mL} / \mathrm{min}, t_{1}=17.66 \mathrm{~min}$ (minor isomer), $t_{2}=25.44$ $\min$ (major isomer)].

\section{Formal Synthesis of Vindorosine}

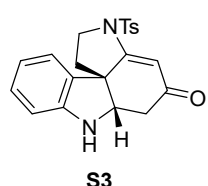

(6aS,11bS)-3-Tosyl-2,3,6a,7-tetrahydro-1H-pyrrolo[2,3-

d] carbazol-5(6H)-one (S3). A mixture of $8(91.0 \mathrm{mg}, 0.193 \mathrm{mmol})$ and $\mathrm{Pd}(\mathrm{OH})_{2} / \mathrm{C}$ (ca. $50 \mathrm{wt} \%$ on carbon, $\left.53 \mathrm{mg}\right)$ in $i-\mathrm{PrOH}(1.0 \mathrm{~mL})$ was stirred under a hydrogen atmosphere at $\mathrm{rt}$ for $12 \mathrm{~h}$. The resulting suspension was filtered through a celite pad, and the pad was washed with EtOAc. The filtrate was concentrated in vacuo. The residue was purified by flash chromatography on silica gel $\left(\mathrm{CHCl}_{3} / \mathrm{MeOH}=20 / 1\right)$ to afford $\mathbf{S 3}$ (21 mg, $0.055 \mathrm{mmol}, 29 \%, 65 \% \mathrm{brsm}$ ) as a white solid: mp 232-237 ${ }^{\circ} \mathrm{C}$; IR $\left(\mathrm{CDCl}_{3}\right) 1612(\mathrm{C}=\mathrm{O}), 1360(\mathrm{O}=\mathrm{S}=\mathrm{O}), 1166$ $(\mathrm{O}=\mathrm{S}=\mathrm{O}) ;{ }^{1} \mathrm{H}$ NMR $\left(500 \mathrm{MHz}, \mathrm{CDCl}_{3}\right) \delta 1.98-2.07(\mathrm{~m}, 2 \mathrm{H}), 2.23(\mathrm{dd}$, $J=16.0,10.0 \mathrm{~Hz}, 1 \mathrm{H}), 2.50(\mathrm{~s}, 3 \mathrm{H}), 2.54(\mathrm{dd}, J=16.5,6.5 \mathrm{~Hz}, 1 \mathrm{H})$, $3.76-3.82(\mathrm{~m}, 2 \mathrm{H}), 3.93(\mathrm{dd}, J=9.5,6.5 \mathrm{~Hz}, 1 \mathrm{H}), 4.03-4.06(\mathrm{~m}, 1 \mathrm{H})$, $6.02(\mathrm{~d}, J=7.5 \mathrm{~Hz}, 1 \mathrm{H}), 6.33(\mathrm{~s}, 1 \mathrm{H}), 6.49-6.52(\mathrm{~m}, 1 \mathrm{H}), 6.72(\mathrm{~d}, J=$ $8.0 \mathrm{~Hz}, 1 \mathrm{H}), 7.07$ (ddd, $J=7.5,7.5,1.5 \mathrm{~Hz}, 1 \mathrm{H}), 7.43(\mathrm{~d}, J=8.0 \mathrm{~Hz}$, $2 \mathrm{H}), 7.90(\mathrm{~d}, J=8.0 \mathrm{~Hz}, 2 \mathrm{H}) ;{ }^{13} \mathrm{C}\left\{{ }^{1} \mathrm{H}\right\}$ NMR $\left(125 \mathrm{MHz}, \mathrm{CDCl}_{3}\right) \delta$ $21.7,35.4,40.8,48.6,54.8,63.8,106.5,111.7,119.7,122.3,127.3$ (2C), 129.1, 129.8, 130.3 (2C), 134.7, 145.5, 147.5, 159.2, 196.2; HRMS (ESI) calcd for $\mathrm{C}_{21} \mathrm{H}_{21} \mathrm{~N}_{2} \mathrm{O}_{3} \mathrm{~S}^{+}[\mathrm{M}+\mathrm{H}]^{+} 381.1267$, found 381.1266 .

(6aS,11bS)-7-Methyl-3-tosyl-2,3,6a,7-tetrahydro-1H-pyrrolo[2,3d] carbazol-5(6H)-one (11). A mixture of $\mathbf{S 3}(21.0 \mathrm{mg}, 0.055 \mathrm{mmol})$ and $37 \% \mathrm{HCHO}$ aq $(170 \mu \mathrm{L})$ in $\mathrm{CH}_{2} \mathrm{Cl}_{2}: \mathrm{MeOH}(10: 1)$ was added to $\mathrm{NaBH}_{3} \mathrm{CN}(14 \mathrm{mg}, 0.221 \mathrm{mmol})$ at $0{ }^{\circ} \mathrm{C}$. The reaction mixture was adjusted to $\mathrm{pH} 3$ and stirred for $1.5 \mathrm{~h}$. The reaction mixture was diluted with $\mathrm{NaHCO}_{3}$ and extracted with $\mathrm{CH}_{2} \mathrm{Cl}_{2}$. The combined organic extracts were washed with brine and dried over $\mathrm{Na}_{2} \mathrm{SO}_{4}$. After concentration in vacuo, the residue was purified by flash chromatography on silica gel $\left(\mathrm{CHCl}_{3} / \mathrm{MeOH}=40 / 1\right)$ to afford $11(22 \mathrm{mg}, 0.055 \mathrm{mmol}$, quant., $74 \% e e$ ) as a white solid: [HPLC, Cosmosil CHiRAL 5B column eluting with $55 \% i-\mathrm{PrOH} / n$-hexane over $30 \mathrm{~min}$ at $0.80 \mathrm{~mL} / \mathrm{min}$, $t_{1}=17.84 \mathrm{~min}$ (minor isomer), $t_{2}=19.18 \mathrm{~min}$ (major isomer)]: $\mathrm{mp}$ 174-177 ${ }^{\circ} \mathrm{C}$; IR $\left(\mathrm{CDCl}_{3}\right) 1616(\mathrm{C}=\mathrm{O}), 1357(\mathrm{O}=\mathrm{S}=\mathrm{O}), 1168$ $(\mathrm{O}=\mathrm{S}=\mathrm{O}) ;{ }^{1} \mathrm{H}$ NMR $\left(500 \mathrm{MHz}, \mathrm{DMSO}-d_{6}\right) \delta 1.75(\mathrm{dd}, J=17.0,9.5$ $\mathrm{Hz}, 1 \mathrm{H}), 1.86(\mathrm{dd}, J=12.0,5.0 \mathrm{~Hz}, 1 \mathrm{H}), 2.10-2.28(\mathrm{~m}, 1 \mathrm{H}), 2.45-2.48$ $(\mathrm{m}, 4 \mathrm{H}), 2.67(\mathrm{~s}, 3 \mathrm{H}), 3.70-3.76(\mathrm{~m}, 1 \mathrm{H}), 4.01(\mathrm{dd}, J=10.0,6.0 \mathrm{~Hz}$, $1 \mathrm{H}), 4.07(\mathrm{dd}, J=10.0,8.0 \mathrm{~Hz}, 1 \mathrm{H}), 5.85(\mathrm{~d}, J=7.5 \mathrm{~Hz}, 1 \mathrm{H}), 5.93(\mathrm{~s}$, $1 \mathrm{H}), 6.40$ (ddd, $J=7.0,7.0,1.0 \mathrm{~Hz}, 1 \mathrm{H}), 6.56(\mathrm{~d}, J=8.0 \mathrm{~Hz}, 1 \mathrm{H})$, 7.08 (ddd, $J=7.5,7.5,1.0 \mathrm{~Hz}, 1 \mathrm{H}), 7.57(\mathrm{~d}, J=8.0 \mathrm{~Hz}, 2 \mathrm{H}), 7.96(\mathrm{~d}$ $J=8.5 \mathrm{~Hz}, 2 \mathrm{H}) ;{ }^{13} \mathrm{C}\left\{{ }^{1} \mathrm{H}\right\}$ NMR (125 MHz, DMSO- $\left.d_{6}\right) \delta 21.1,31.4$, $34.59,34.62,48.8,53.4,68.3,105.5,108.7,117.9,121.2,127.2(2 \mathrm{C})$ 129.0, 130.6 (3C), 134.1, 145.8, 149.0, 159.4, 195.2; HRMS (ESI) calcd for $\mathrm{C}_{22} \mathrm{H}_{23} \mathrm{~N}_{2} \mathrm{O}_{3} \mathrm{~S}^{+}[\mathrm{M}+\mathrm{H}]^{+} 395.1424$, found 395.1425 . The spectral data were in good agreement with those previously reported. ${ }^{14}$

(6aS,11bS,E)-7-Benzyl- $N$-[(R)-2-(methoxymethyl)pyrrolidin-1-yl]3-tosyl-2,3,6a,7-tetrahydro-1 $H$-pyrrolo $[2,3-d \mid$ carbazol-5(6H)-

imine (10). A mixture of racemic $8(100.0 \mathrm{mg}, 0.21 \mathrm{mmol})$ and $(R)-1$ amino-2-(methoxymethyl)pyrrolidine $9(56 \mu \mathrm{L}, 0.043 \mathrm{mmol})$ in toluene $(1.0 \mathrm{~mL})$ was stirred at $95{ }^{\circ} \mathrm{C}$ for $24 \mathrm{~h}$. The reaction mixture was concentrated in vacuo. The residue was purified by flash chromatography on amine silica gel (hexane/EtOAc $=4 / 1)$ to afford $\mathbf{1 0}(9.6 \mathrm{mg}$, $0.016 \mathrm{mmol}, 8 \%)$ as a white solid. This material was recrystallized from MeCN: $\mathrm{mp} 88-92{ }^{\circ} \mathrm{C} ;[\alpha]^{26} \mathrm{D}-206.2\left(\mathrm{c} 0.48, \mathrm{CHCl}_{3}\right)$; IR $\left(\mathrm{CDCl}_{3}\right)$ 1643, $1600(\mathrm{C}=\mathrm{N}), 1355(\mathrm{O}=\mathrm{S}=\mathrm{O}), 1166(\mathrm{O}=\mathrm{S}=\mathrm{O}) ;{ }^{1} \mathrm{H}$ NMR $(500$ $\left.\mathrm{MHz}, \mathrm{CDCl}_{3}\right) \delta 1.64-1.73(\mathrm{~m}, 2 \mathrm{H}), 1.78-1.84(\mathrm{~m}, 2 \mathrm{H}), 1.90-2.06(\mathrm{~m}$, $3 \mathrm{H}), 2.29-2.34(\mathrm{~m}, 1 \mathrm{H}), 2.48(\mathrm{~s}, 3 \mathrm{H}), 3.07-3.11(\mathrm{~m}, 1 \mathrm{H}), 3.20-3.27(\mathrm{~m}$, $2 \mathrm{H}), 3.33-3.36(\mathrm{~m}, 4 \mathrm{H}), 3.41-3.43(\mathrm{dd}, J=9.0,4.0 \mathrm{~Hz}, 1 \mathrm{H}), 3.57-3.65$ $(\mathrm{m}, 2 \mathrm{H}), 3.95(\mathrm{t}, J=8.0 \mathrm{~Hz}, 1 \mathrm{H}), 4.23(\mathrm{~d}, J=15.0 \mathrm{~Hz}, 1 \mathrm{H}), 4.36(\mathrm{~d}, J$ $=15.0 \mathrm{~Hz}, 1 \mathrm{H}), 5.65(\mathrm{~d}, J=7.0 \mathrm{~Hz}, 1 \mathrm{H}), 6.31-6.35(\mathrm{~m}, 2 \mathrm{H}), 6.54(\mathrm{~s}$, $1 \mathrm{H}), 6.98(\mathrm{t}, J=8.0 \mathrm{~Hz}, 1 \mathrm{H}), 7.27-7.37(\mathrm{~m}, 5 \mathrm{H}), 7.40(\mathrm{~d}, J=8.0 \mathrm{~Hz}$, 2H), $7.90(\mathrm{~d}, J=8.0 \mathrm{~Hz}, 2 \mathrm{H}) ;{ }^{13} \mathrm{C}\left\{{ }^{1} \mathrm{H}\right\}$ NMR $\left(125 \mathrm{MHz}, \mathrm{CDCl}_{3}\right) \delta$ 
$21.6,22.5,25.7,26.6,36.1,47.7,49.2,53.3,54.4,59.2,66.6,67.8$, $75.4,107.8,108.7,117.9,122.2,127.27$ (2C), 127.30 (3C), 128.4, 128.6 (2C), 130.0 (2C), 132.4, 135.3, 137.9, 144.3, 144.5, 148.2, 158.3; HRMS (ESI) calcd for $\mathrm{C}_{34} \mathrm{H}_{39} \mathrm{~N}_{4} \mathrm{O}_{3} \mathrm{~S}^{+}[\mathrm{M}+\mathrm{H}]^{+}$583.2737, found 583.2735 .

\section{(6aS,11bS)-7-Benzyl-3-tosyl-2,3,6a,7-tetrahydro- $1 H$-pyrrolo[2,3-} $d]$ carbazol-5(6H)-one $[(S, S)-(+)-8]$. A mixture of $10(5.8 \mathrm{mg}, 0.010$ $\mathrm{mmol})$ and MeI $(6.2 \mu \mathrm{L}, 0.10 \mathrm{mmol})$ in THF $(0.2 \mathrm{~mL})$ was stirred at $55{ }^{\circ} \mathrm{C}$ for $48 \mathrm{~h}$. The reaction mixture was concentrated in vacuo. The reaction mixture was diluted with water and extracted with EtOAc. The combined organic layers were washed with brine and dried over $\mathrm{Na}_{2} \mathrm{SO}_{4}$. After concentration in vacuo, the residue was purified by flash chromatography on silica gel (hexane/EtOAc $=2 / 1$ ) to afford 8 (2.0 mg, $0.0043 \mathrm{mmol}, 43 \%):[\alpha]^{25} \mathrm{D}+84.3\left(\mathrm{c} 0.13, \mathrm{CHCl}_{3}\right)$.

\section{ASSOCIATED CONTENT}

\section{Supporting Information}

The Supporting Information is available free of charge via the Internet at http://pubs.acs.org.

Optimization of the Asymmetric Reaction, X-ray crystal structure and crystal data of compound 10, HPLC chromatograms, and ${ }^{1} \mathrm{H}$ and ${ }^{13} \mathrm{C}\left\{{ }^{1} \mathrm{H}\right\}$ NMR spectra for all compounds (PDF)

\section{AUTHOR INFORMATION}

\section{Corresponding Author}

*hohno@pharm.kyoto-u.ac.jp

\section{Notes}

The authors declare no competing financial interest.

\section{ACKNOWLEDGMENT}

This work was supported by the JSPS KAKENHI (JP15KT0061, JP17H03971, JP18H04408, and JP18J12107), the Platform Project for Supporting Drug Discovery and Life Science Research (Platform for Drug Discovery, Informatics, and Structural Life Science) from AMED (Grant Number J17am0101092j0001), and the Hoansha Foundation. J.M. is grateful for the JSPS Research Fellowships for Young Scientists.

\section{REFERENCES}

(1) (a) Aquino, P. G. V.; de Aquino, T. M.; Alexandre-Moreira, M. S.; de Oliveira Santos, B. V.; Santana, A. E. G.; de Araújo-Júnior, J. X. Aspidosperma Terpenoid Alkaloids - Biosynthetic Origin, Chemical Synthesis and Importance; InTech, 2015. (b) Saxton, J. E. The Alkaloids: Chemistry and Biology; Academic Press: 1998.

(2) (a) Moncrief, J. W.; Lipscomb, W. N. Structures of Leurocristine (Vincristine) and Vincaleukoblastine. ${ }^{1}$ X-Ray Analysis of Leurocristine Methiodide. J. Am. Chem. Soc. 1965, 87, 4963-4964. (b) Noble, R. L. The Discovery of the Vinca AlkaloidsChemotherapeutic Agents against Cancer. Biochem. Cell Biol. 1990, 68, 1344-1351.

(3) (a) Gorman, M.; Neuss, N.; Biemann, K. J. Am. Chem. Soc. 1962, 84, 1058-1059. (b) Moza, B.; Trojánek, J. On Alkaloids. VIII. Structure of Vindorosine. Collect. Czech. Chem. Commun. 1963, 28, 1427-1433.

(4) Martin, M. T.; Rasoanaivo, P.; Palazzino, G.; Galeffi, C.; Nicoletti, M.; Trigalo, F.; Frappier, F. Minor $\mathrm{N}_{\mathrm{b}}, \mathrm{C}(21)$-Secocuran Alkaloids of Strychnos myrtoides. Phytochemistry 1999, 51, 479-486.

(5) Büchi, G.; Matsumoto, K. E.; Nishimura, H. Total Synthesis of ( \pm )-Vindorosine. J. Am. Chem. Soc. 1971, 93, 3299-3301.

(6) Kuehne, M. E.; Podhorez, D. E.; Mulamba, T.; Bornmann, W. G. Biomimetic Alkaloid Syntheses. 15. Enantioselective Syntheses with Epichlorohydrin: Total Syntheses of (+)-, (-)-, and $( \pm)$-Vindoline and a Synthesis of (-)-Vindorosine. J. Org. Chem. 1987, 52, 347-353.
(7) (a) Elliott, G. I.; Velcicky, J.; Ishikawa, H.; Li, Y.; Boger, D. L. Total Synthesis of (-)-and ent-(+)-Vindorosine: Tandem Intramolecular Diels-Alder/1,3-Dipolar Cycloaddition of 1,3,4-Oxadiazoles. Angew. Chem., Int. Ed. 2006, 45, 620-622. (b) Ishikawa, H.; Elliott, G. I.; Velcicky, J.; Choi, Y.; Boger, D. L. Total Synthesis of (-)- and ent-(+)-Vindoline and Related Alkaloids. J. Am. Chem. Soc. 2006, 128, 10596-10612. (c) Sasaki, Y.; Kato, D.; Boger, D. L. Asymmetric Total Synthesis of Vindorosine, Vindoline, and Key Vinblastine Analogues. J. Am. Chem. Soc. 2010, 132, 13533-13544.

(8) Chen, W.; Yang, X.; Tan, W.; Zhang, X.; Liao, X.; Zhang, H. Total Synthesis of (-)-Vindorosine. Angew. Chem., Int. Ed. 2017, 56, $12327-12331$.

(9) For a review article on ynamides, see: (a) DeKorver, K. A.; Li, H.; Lohse, A. G.; Hayashi, R.; Lu, Z.; Zhang, Y.; Hsung, R. P. Ynamides: A Modern Functional Group for the New Millennium. Chem. Rev. 2010, 110, 5064-5106. (b) Pan, F.; Shu, C.; Ye, L.-W. Recent Progress towards Gold-Catalyzed Synthesis of N-Containing Tricyclic Compounds Based on Ynamides. Org. Biomol. Chem. 2016, 14, 9456-9465.

(10) For gold-catalyzed reaction of ynamides with azides, see: (a) Shu, C.; Wang, Y.-H.; Zhou, B.; Li, X.-L.; Ping, Y.-F.; Lu, X.; Ye, L.-W. Generation of $\alpha$-Imino Gold Carbenes through Gold-Catalyzed Intermolecular Reaction of Azides with Ynamides. J. Am. Chem. Soc. 2015, 137, 9567-9570. (b) Pan, Y.; Chen, G.-W.; Shen, C.-H.; He, W.; Ye, L.-W. Synthesis of Fused Isoquinolines via Gold-Catalyzed Tandem Alkyne Amination/Intramolecular O-H Insertion. Org. Chem. Front. 2016, 3, 491-495. (c) Shen, W.-B.; Sun, Q.; Li, L.; Liu, X.; Zhou, B.; Yan, J.-Z.; Lu, X.; Ye, L.-W. Divergent Synthesis of NHeterocycles via Controllable Cyclization of Azido-diynes Catalyzed by Copper and Gold. Nat. Commun. 2017, 8, 1748.

(11) For recent reports on related gold-catalyzed cyclization of ynamides, see: (a) Pan, F.; Liu, S.; Shu, C.; Lin, R.-K.; Yu, Y.-F.; Zhou, J.-M.; Ye, L.-W. Gold-Catalyzed Intermolecular Oxidation of $o$-Alkynylbiaryls: an Easy and Practical Access to Functionalized Fluorenes. Chem. Commun. 2014, 50, 10726-10729. (b) Adcock, H. V.; Chatzopoulou, E.; Davies, P. W. Divergent C-H InsertionCyclization Cascades of $N$-Allyl Ynamides. Angew. Chem., Int. Ed. 2015, 54, 15525-15529. (c) Liu, J.; Chen, M.; Zhang, L.; Liu, Y. Gold(I)-Catalyzed 1,2-Acyloxy Migration/[3+2] Cycloaddition of 1,6Diynes with an Ynamide Propargyl Ester Moiety: Highly Efficient Synthesis of Functionalized Cyclopenta $[b]$ indoles. Chem. Eur. J. 2015, 21, 1009-1013. (d) Nayak, S.; Ghosh, N.; Prabagar, B.; Sahoo, A. K. $p$-TsOH Promoted Au(I)-Catalyzed Consecutive Endo Cyclization of Yne-Tethered Ynamide: Access to Benzofused Dihydroisoquinolones. Org. Lett. 2015, 17, 5662-5665. For a related goldcatalyzed oxidative reaction, see: (e) Lin, M.; Zhu, L.; Xia, J.; Yu, Y.; Chen, J.; Mao, Z.; Huang, X. Gold-Catalyzed Oxidative Cyclization of Tryptamine Derived Enynamides: A Stereoselective Approach to Tetracyclic Spiroindolines. Adv. Synth. Catal. 2018, 360, 2280-2284.

(12) Zheng, N.; Chang, Y.-Y.; Zhang, L.-J.; Gong, J.-X.; Yang, Z. Gold-Catalyzed Intramolecular Tandem Cyclization of IndoleYnamides: Diastereoselective Synthesis of Spirocyclic Pyrrolidinoindolines. Chem. Asian J. 2016, 11, 371-375.

(13) (a) Dankwardt, J. W. Transition-Metal-Promoted 6-endo-dig Cyclization of Aromatic Enynes: Rapid Synthesis of Functionalized Naphthalenes. Tetrahedron Lett. 2001, 42, 5809-5812. (b) Nevado, C.; Cárdenas, D. J.; Echavarren, A. M. Reaction of Enol Ethers with Alkynes Catalyzed by Transition Metals: 5-exo-dig versus 6-endo-dig Cyclizations via Cyclopropyl Platinum or Gold Carbene Complexes. Chem. Eur. J. 2003, 9, 2627-2635. (c) Staben, S. T.; Kennedy-Smith, J. J.; Huang, D.; Corkey, B. K.; LaLonde, R. L.; Toste, F. D. Gold(I)Catalyzed Cyclizations of Silyl Enol Ethers: Application to the Synthesis of (+)-Lycopladine A. Angew. Chem., Int. Ed. 2006, 45, 59915994. (d) Minnihan, E. C.; Colletti, S. L.; Toste, F. D.; Shen, H. C. Gold(I)-Catalyzed Regioselective Cyclizations of Silyl Ketene Amides and Carbamates with Alkynes. J. Org. Chem. 2007, 72, 62876289. (e) Ito, H.; Ohmiya, H.; Sawamura, M. Construction of Methylenecycloheptane Frameworks through 7-Exo-Dig Cyclization of Acetylenic Silyl Enol Ethers Catalyzed by Triethynylphosphine-Gold Complex. Org. Lett. 2010, 12, 4380-4383. 
(14) Wang, Y.; Lin, J.; Wang, X.; Wang, G.; Zhang, X.; Yao, B.; Zhao, Y.; Yu, P.; Lin, B.; Liu, Y.; Cheng, M. Brønsted AcidCatalyzed Tandem Cyclizations of Tryptamine-Ynamides Yielding $1 H$-Pyrrolo[2,3- $d]$ carbazole Derivatives. Chem. Eur. J. 2018, 24, 4026-4032.

(15) Mansfield, S. J.; Campbell, C. D.; Jones, M. W.; Anderson, E. A. A Robust and Modular Synthesis of Ynamides. Chem. Commun. 2015, 51, 3316-3319.

(16) Preparation of the corresponding TBS-protected enol ether failed because of its lower stability compared with the TIPS derivative 7. Similarly, preparation of the $N$-methyl indole derivative was difficult due to the instability of the $N$-methyl derivative of type $\mathbf{5}$ under oxidation conditions.

(17) For a review article, see : (a) Wang, Y.; Lackner, A. D.; Toste, F. D. Development of Catalysts and Ligands for Enantioselective Gold Catalysis. Acc. Chem. Res. 2014, 47, 889-901. For selected gold-catalyzed asymmetric reactions, see: (b) LaLonde, R. L.; Sherry, B. D.; Kang, E. J.; Toste, F. D. Gold(I)-Catalyzed Enantioselective Intramolecular Hydroamination of Allenes. J. Am. Chem. Soc. 2007, 129, 2452-2453. (c) Bandini, M.; Eichholzer, A. Enantioselective Gold-Catalyzed Allylic Alkylation of Indoles with Alcohols: An Efficient Route to Functionalized Tetrahydrocarbazoles. Angew. Chem.,
Int. Ed. 2009, 48, 9533-9537. (d) Sethofer, S. G.; Mayer, T.; Toste, F. D. Gold(I)-Catalyzed Enantioselective Polycyclization Reactions. $J$. Am. Chem. Soc. 2010, 132, 8276-8277. (e) González, A. Z.; Toste, F. D. Gold(I)-Catalyzed Enantioselective [4 + 2]-Cycloaddition of Allene-dienes. Org. Lett. 2010, 12, 200-203. (f) Brazeau, J.; Zhang, S.; Colomer, I.; Corkey, B. K.; Toste, F. D. Enantioselective Cyclizations of Silyloxyenynes Catalyzed by Cationic Metal Phosphine Complexes. J. Am. Chem. Soc. 2012, 134, 2742-2749. (g) Cera, G.; Chiarucci, M.; Mazzanti, A.; Mancinelli, M.; Bandini, M. Enantioselective GoldCatalyzed Synthesis of Polycyclic Indolines. Org. Lett. 2012, 14, 1350-1353. (h) Wang, Z.; Nicolini, C.; Hervieu, C.; Wong, Y.; Zanoni, G.; Zhang, L. Remote Cooperative Group Strategy Enables Ligands for Accelerative Asymmetric Gold Catalysis. J. Am. Chem. Soc. 2017, 139, 16064-16067.

(18) Johansson, M. J.; Gorin, D. J.; Staben, S. T.; Toste, F. D. Gold(I)-Catalyzed Stereoselective Olefin Cyclopropanation. J. Am. Chem. Soc. 2005, 127, 18002-18003.

(19) Melhado, A. D.; Luparia, M.; Toste, F. D. Au(I)-Catalyzed Enantioselective 1,3-Dipolar Cycloadditions of Münchnones with Electron-Deficient Alkenes. J. Am. Chem. Soc. 2007, 129, 1263812639 . 